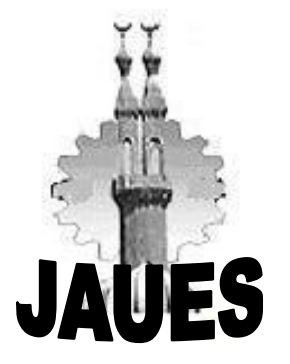

Journal of Al Azhar University Engineering Sector

Vol. 13, No. 49, October, 2018, 1290-1299

\title{
ENHANCEMENT MAXIMUM POWER POINT TRACKING OF PV SYSTEMS USING DIFFERENT ALGORITHMS
}

\author{
Yasmin Gharib ${ }^{1}$, Wagdy R. Anis ${ }^{2}$ and M. A. AbdelRahim ${ }^{2}$ \\ Department of Electrical Engineering, British university in Egypt, Cairo, Egypt ${ }^{1}$ \\ Department of Electrical Engineering, Ain Shams University, Cairo, Egypt ${ }^{2}$
}

\begin{abstract}
In the last decades, the use of renewable energy resources instead of fossil fuels pollution has increased exponentially to overcome the rapid growth of energy demand. This paper, presents a Perturb and Observe (P\&O) algorithm and Incremental conductance technique for extracting the maximum power from a stand-alone PV for use in pumping system. The PV system comprises a solar panel, DC-DC boost converter, MPPT and permanent DC motor driving a Centrifugal pump. Results are accomplished by modelling and simulating the complete MPPT with PV pumping system using MATLAB/Simulink .MPPT algorithms performance is measured to confirm its significantly improved power extraction performance under different sunlight condition.
\end{abstract}

KEYWORDS: Photovoltaic array, Boost converter, Maximum Power Point Tracking, Perturb and Observe algorithm, Incremental conductance Technique, Photovoltaic water pumping system.

\section{INTRODUCTION}

Photovoltaic systems (PV) are one of many resources of renewable energy; these systems are providing a clean infinite and domestic source of energy. It is heavily encourage using unlimited green source of energy, which reduces global carbon emissions; therefore it has a lower effect on the environment, and plays an important role in the energy security of nations when the dependency on imported sources is reduced. Solar energy is often considered the best power source for applications, such as water pumping in rural areas in developing countries. Previous studies on photovoltaicgenerator driven water pumping systems have previously considered a number of suitable pumps and motors $[1,2]$.

It is important to improve the performance of the PV system and to extract the maximum power point under any environmental condition is necessary to track the maximum power point using control methods. The MPPT algorithm calculates the MPP in each instant of time for any irradiance and temperature[3].the DC motor and pump are operating the PV array far from the MPP.Due to nonlinear V/I characteristics of the PV array. It is challenging to track the MPP to avoid these problems; many algorithms have been developed to provide maximum power.

This paper provide a comparative study on maximum power point tracking (MPPT) controller for boost converter based on Perturb and Observe (P\&O) algorithm and Incremental conductance technique applied to PV array, DC motor and pump. The system is simulated and analyzed using Matlab/Simulink and the energy efficiency is calculated for different level of irradiation. 


\section{PV SYSTEM MODELLING}

A PV cell can be modelled using a current source in parallel with a diode, but all the energy that is generated by the PV cell is not transferred to the external circuit. To account for the power drop, series and parallel resistances are used in the model.

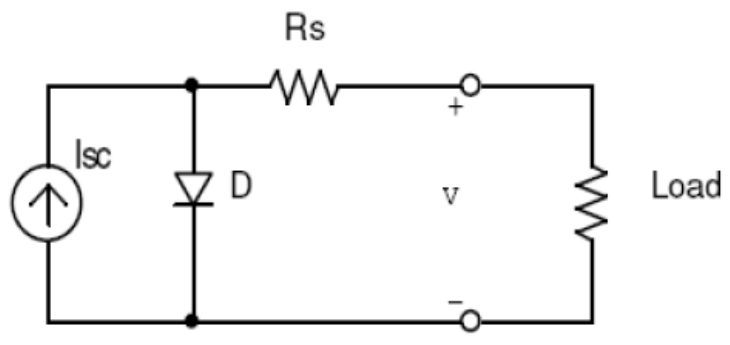

Fig. 1. Single diode model of PV cell.

The current (assuming $\mathrm{R}_{\text {sh }}$ is high and is neglected) that can be derived from a PV cell is given by (1), which is dependent on isolation and ambient temperature.

$$
I=I_{s h}-I_{o}\left[e^{\left.e^{\top}(q((V+I R) / n k T))-1\right]}\right.
$$

Where: $\mathbf{I}$ is the cell current, $\mathbf{V}$ is the cell voltage, $\mathbf{T}$ is the cell temperature in Kelvin $(\mathrm{K}), \mathbf{I}_{\mathbf{0}}$ is the reverse saturation current of diode $(\mathrm{A}), \mathrm{q}$ is the electron charge $(1.602 \times 10-19 \mathrm{C}), \mathbf{K}$ is the Boltzmann's constant $(1.381 \times 10-23 \mathrm{~J} / \mathrm{K})$.

First, calculate the short-circuit current (Isc) at a given cell temperature (T):

$$
\mathrm{I}_{\mathrm{sc}}(\mathrm{T})=\mathrm{I}_{\mathrm{sc}}\left(\mathrm{T}_{\mathrm{ref}}\right) .\left[1+\mathrm{a}\left(\mathrm{T}-\mathrm{T}_{\mathrm{ref}}\right)\right]
$$

Where: $\mathbf{I}_{\text {sc }}$ at $\mathbf{T}_{\text {ref }}$ is given in the datasheet (measured under irradiance of $1000 \mathrm{~W} / \mathrm{m} 2$ ), $\mathbf{T}_{\text {ref }}$ is the reference temperature of $\mathrm{PV}$ cell in Kelvin $(\mathrm{K})$, usually $298^{\circ} \mathrm{K}\left(25^{\circ} \mathrm{C}\right)$, a is the temperature coefficient of $\mathbf{I}_{\mathbf{s c}}$ in percent change per degree temperature, it is also given in the datasheet.

The short-circuit current $\left(\mathbf{I}_{\text {sc }}\right)$ is proportional to the intensity of irradiance, thus $I_{\mathrm{sc}}$ at a given irradiance $(\mathrm{G})$ is:

$$
I_{\mathrm{sc}}(\mathrm{G})=\left(\frac{\mathbf{G}}{\mathbf{G} \text { 国 }}\right) I_{\mathrm{sc}}\left(\mathrm{G}_{\mathrm{o}}\right)
$$

Where: Go is the nominal value of irradiance, which is normally $1000 \mathrm{~W} / \mathrm{m} 2$. The reverse saturation current of diode $\left(\mathbf{I}_{\mathbf{0}}\right)$ at the reference temperature $\left(\mathbf{T}_{\text {ref }}\right)$ is given by:

$I_{0}=\frac{\text { Isc }}{\left(e^{\frac{\text { qVoc }}{\sqrt{ } k T}}-1\right)}$

The reverse saturation current $\left(\mathrm{I}_{\mathrm{o}}\right)$ at a given temperature $(\mathrm{T})$ is calculated by the following equation:

$$
I_{o}=I_{o}\left(T_{\text {ref }}\right) .\left(\frac{T}{\text { Tref }}\right)^{\frac{3}{n}} e^{\frac{-q E g}{n k\left(\frac{1}{T}-\frac{1}{\nabla_{\text {ref }}}\right)}}
$$

The equation for $R_{s}$ at the open circuit voltage is:

$R_{S}=-\frac{d V}{d I(V I r)}-\frac{\frac{n k T}{q}}{I o \cdot e^{\frac{\sqrt{n V o c}}{n k T}}}$

(6)

\section{Modelling OF DC WATER PUMP}


Permanent magnet DC Motor: While the output produced by PV generators is DC power, a DC motor is usually employed as a replacement for of AC motors in the PV pumping systems, because DC motors can be more easily interfaced with PV generators without using DC to AC power conversion. Therefore, the overall system cost and complexity will significantly reduce. In this work, a permanent magnet DC motor is used to drive a centrifugal pump load. The permanent magnet DC motor has some advantages such as reliability, high efficiency and relatively infrequent maintenance [4]. Moreover, the PMDC motor coupled with centrifugal pump has suitable matching characteristics with the PV array characteristics and its starting low torque is low compared to other PV electromechanical systems [4] and [5].Fig 2. illustrates the equivalent circuit of the permanent magnet DC motor with the pump load.

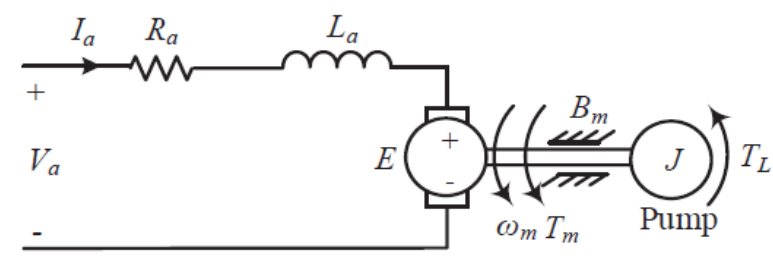

Fig. 2: Circuit model for PMDC motor with pump load.

In Fig. $2, \mathrm{R}_{\mathrm{a}}$ is the armature winding resistance $(\Omega), \mathrm{L}_{\mathrm{a}}$ is the armature self-inductance $(H), \mathrm{I}_{\mathrm{a}}$ is the motor armature current $(\mathrm{A})$ and $\mathrm{V}_{\mathrm{a}}$ is the applied voltage $(\mathrm{V})$.

According to the equivalent circuit shown in Fig. 2, the armature DC voltage can be calculated using equation (7).

$$
\mathrm{V}_{\mathrm{a}}=\mathrm{R}_{\mathrm{a}} \mathrm{I}_{\mathrm{a}}+\mathrm{L}_{\mathrm{a}} \frac{\text { dIa }}{\text { 目 }}+\mathrm{K}_{\mathrm{e}} \mathrm{W}_{\mathrm{m}}
$$

(7)

e is the induced voltage when the motor is turning, and is known as a back emf. The induced voltage e is proportional to the angular speed of the rotor $\left(\omega_{\mathrm{m}}\right)$ and the back emf constant proportionality $\left(\mathrm{K}_{\mathrm{e}}\right)$ as given by:

$$
\left(\mathrm{e}=\mathrm{K}_{\mathrm{e}} \omega_{\mathrm{m}}\right)
$$

The torque balance equation is given by equation (9).

$$
\mathrm{Te}=\mathrm{K}_{\mathrm{t}} \mathrm{I}_{\mathrm{a}}=\mathrm{J} \frac{\mathbf{d} \boldsymbol{\mathrm { m }}}{\text { 目 }}+\mathrm{B}_{\mathrm{m}} \omega_{\mathrm{m}}+\mathrm{T}_{\mathrm{L}}
$$

Where $\mathbf{K}_{\mathbf{t}}$ is the torque constant, $\mathbf{J}$ is the moment of inertia, $\mathbf{B}_{\mathbf{m}}$ is the torque constant for rotational losses, $\mathbf{T}_{\mathbf{e}}$ and $\mathbf{T}_{\mathbf{L}}$ are the electromagnetic torque and the load torque respectively.

Centrifugal pump load: There are two types of pump usually used in PV pumping systems: volumetric pump and the centrifugal pump. However, it was reported in [6] that, a load composed of a DC motor driving a constant volumetric pump represents a non-matched load for a PV generator because the motor driving a constant volumetric pump requires a nearly constant current. Conversely, it was found in [7] that the PV sourced energy utilized by the centrifugal pump is much higher than with the volumetric pump, because the centrifugal pump works for longer periods even for low insolation levels. Moreover, the characteristics of the DC motor and centrifugal pump combination are well matched with the maximum power locus of the PV generator. Centrifugal pumps are inexpensive, simple, require low maintenance and are available in a wide range of flow rates and heads. Therefore, a centrifugal pump is considered in this work.

The centrifugal pump load develops speed-dependent torque. The speed-torque relationship for a centrifugal pump including friction torque is given by equation (10) [8].

$$
\mathrm{T}_{\mathrm{p}}=\mathrm{T}_{\mathrm{L}}=\mathrm{A}_{\mathrm{L}} \mathrm{K}_{\mathrm{L}} \omega_{\mathrm{m}} 1.8
$$


$\mathbf{T}_{\mathbf{p}}$ is the torque required to drive the pump, $\mathbf{A}_{\mathbf{L}}$ is the load friction $(\mathrm{Nm})$ and $\mathbf{K}_{\mathbf{L}}$ the proportional constant of the load torque N.m /(rad/sec $)^{2}$.

\section{MaXimum Power Point Tracker}

The MPPT technique uses a DC-DC converter in order to allow the PV module to operate at its maximum power. This is achieved by an intelligent algorithm to solve the problems are related to the variation of temperature, the insolation and module load. Many tracking algorithms have been proven and used with variety of kind of DC-DC converters [9-11] among these algorithms, the Perturb \& Observe (P\&O) and Incremental Conductance (INC) methods are studied here.

It is to notice that the choice of the DC-DC converter in a photovoltaic system is important when a highest efficiency of the MPPT is desired. The boost DC-DC converter as shown in Fig 3. is able to follow the photovoltaic panel maximum power point, regardless of cell temperature, solar global irradiation and connected load.

The following voltage transfer function is:

$$
\frac{\text { Vo }}{\text { Vi }}=\frac{1}{1-D}
$$

The above equation shows that the output voltage is always higher than the input voltage (as the duty cycle goes from 0 to 1 ).

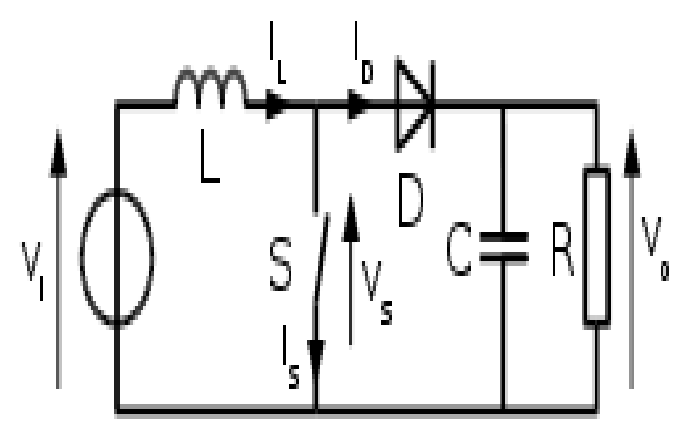

Fig. 3.boost DC-DC converter

Perturb \& Observe Algorithm : The perturb \& observe (P\&O) algorithm, also known as the "hill climbing" method, is very popular and the most commonly used in practice because of its simplicity in algorithm and the ease of implementation. Fig. 4 shows the P-V curve, at the constant irradiance and the constant module temperature, assuming the PV module is operating at a point, which is away from the MPP. In this algorithm, the operating voltage of the PV module is perturbed by a small increment, and the resulting change of power, $\Delta \mathrm{P}$, is observed. If the $\Delta \mathrm{P}$ is positive, then it is supposed that it has moved the operating point closer to the MPP. Thus, further voltage perturbations in the same direction should move the operating point toward the MPP. If the $\triangle \mathrm{P}$ is negative, the operating point has moved away from the MPP, and the direction of perturbation should be reversed to move back toward the MPP. Fig. 5 shows the flowchart of this algorithm [9]. 


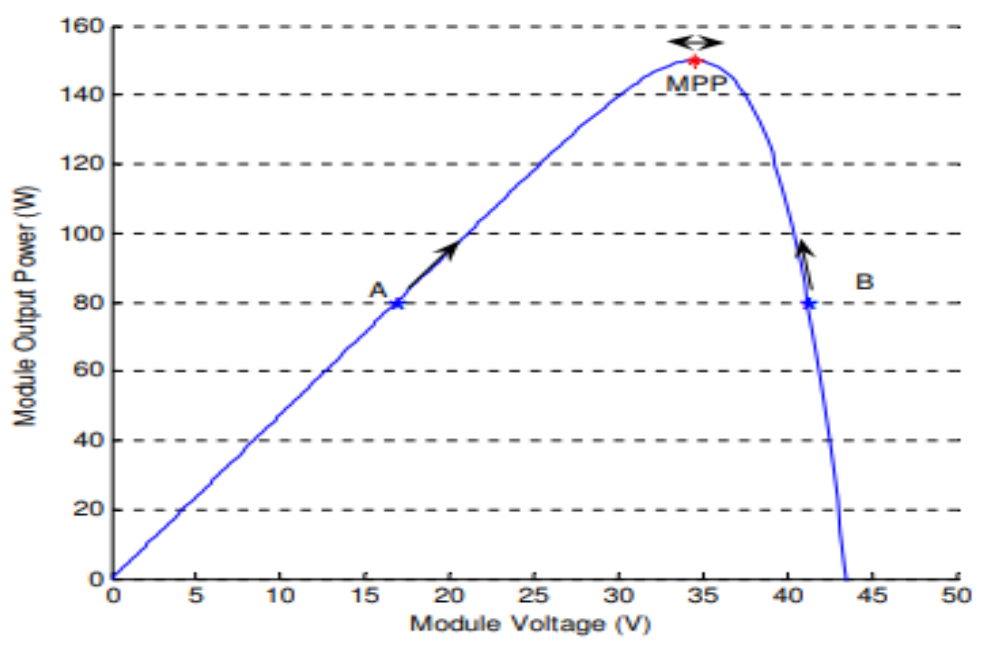

Fig. 4: $\mathrm{P}-\mathrm{V}$ curve $\left(1000 \mathrm{~W} / \mathrm{m} 2,2^{\circ} \mathrm{C}\right)$

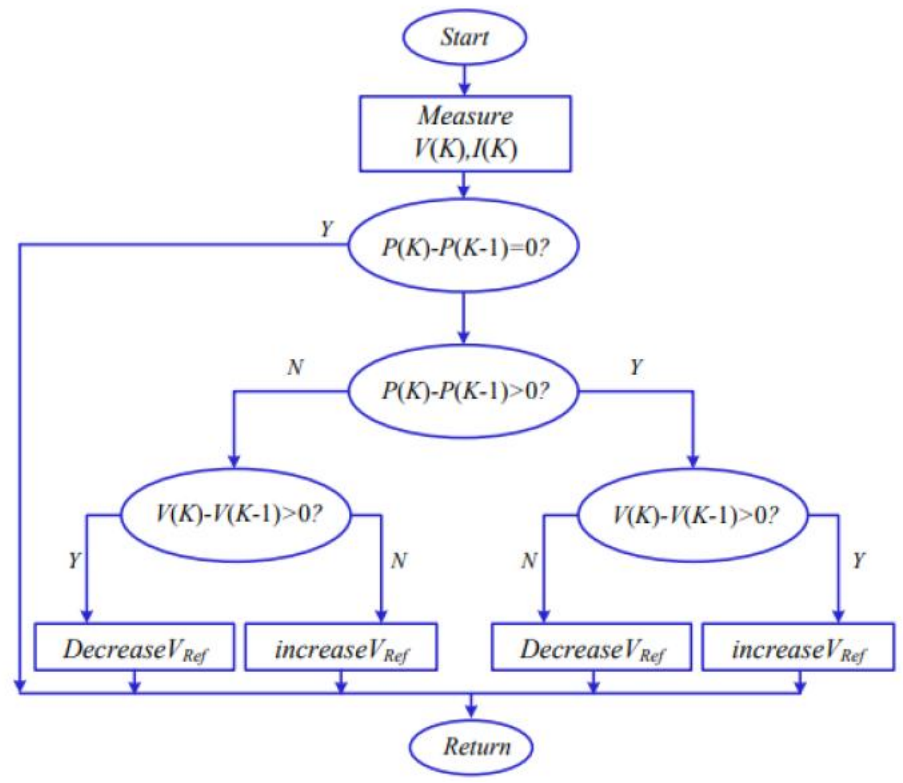

Fig.5: Flowchart of the $P \& O$ algorithm

Incremental Conductance Algorithm: The basic idea is that the slope of P-V curve becomes zero at the MPP, as shown in Fig 4. It is also possible to find a relative location of the operating point to the MPP by looking at the slopes. The slope is the derivative of the PV module's power with respect to its voltage and has the following relationships with the MPP [9]. Fig 6 shows the flowchart of incremental conductance method.

$$
\begin{aligned}
& \frac{d P}{d V}=0 \\
& \text { at MPP. }
\end{aligned}
$$

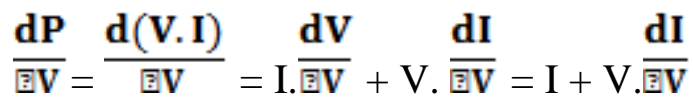


At MPP: $\quad I+V \cdot \frac{\text { dI }}{\text { IIV }}=0 \Rightarrow \frac{\text { dI }}{\text { IV }}=-\frac{\text { I }}{\text { I }}$

If the operating point is at the right side of the MPP, the equation (14) becomes:

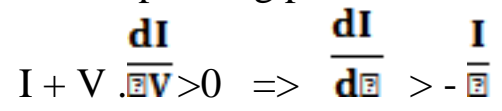

If the operating point is at the left side of the MPP, the equation (14) becomes:

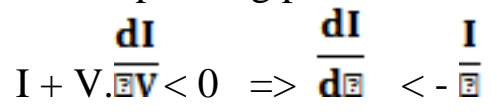

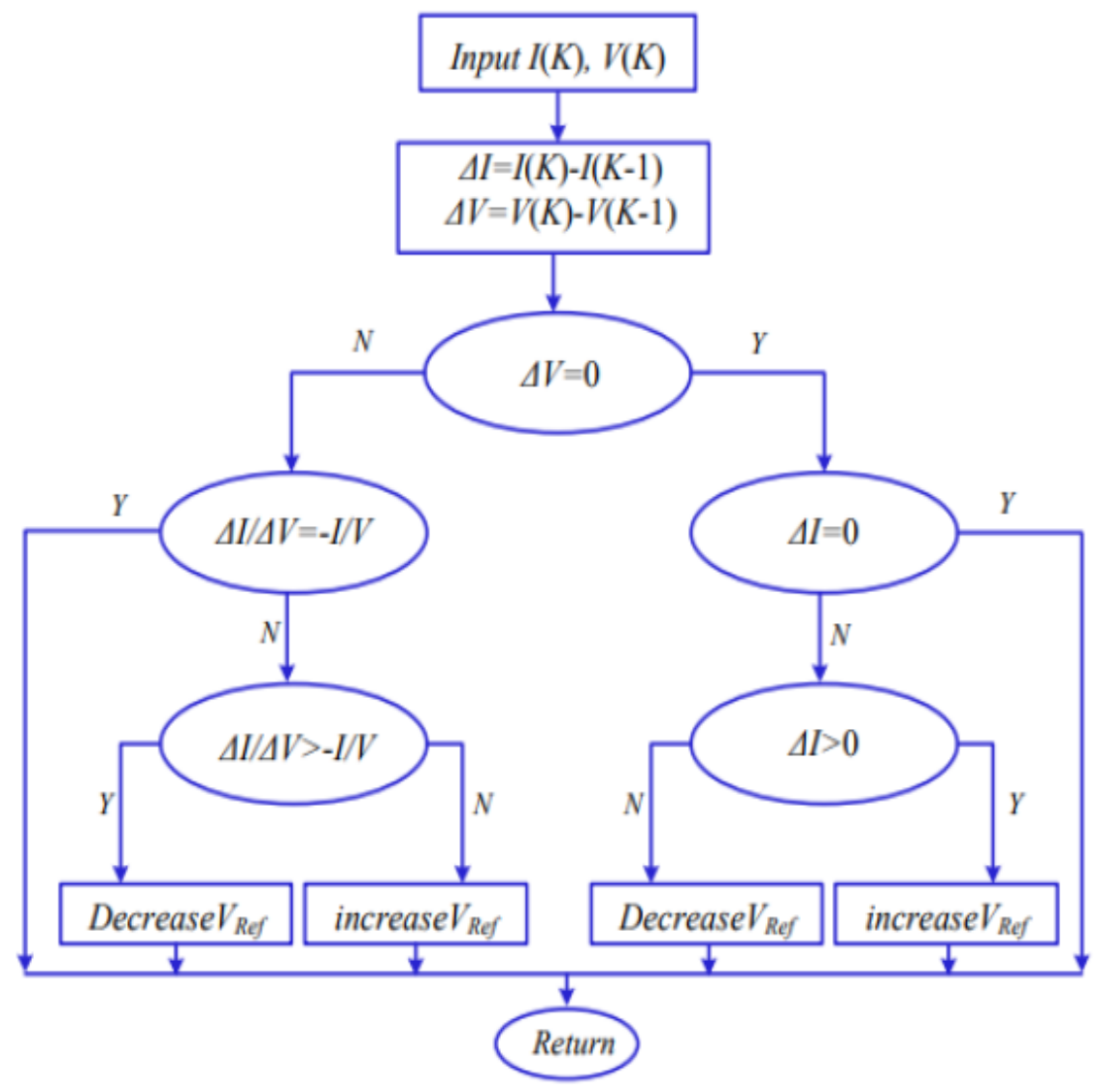

\section{Simulation MODELS AND RESULTS}

Fig.6: Flowchart of the INC algorithm.

The system is modelled in MATLAB/Simulink. A boost converter is used to interface a PV array with dc motor pumping system in Fig 7. To perform the maximum power point tracking, both $\mathrm{P} \& \mathrm{O}$ and IC algorithms have been implemented with all consideration of the optimization techniques. The simulation allows verification of the feasibility and relative performance of both algorithms under correctly the same conditions. Here, the main aspect to consider is the dynamic performance in terms of the speed at which the system converges on maximum power point, and the ripple in the power due to oscillations around the maximum power point is at steady state conditions. Both I-V and PV output characteristics of generalized PV model for a cell are shown in Fig. 8 and Table I shows parameters of Parameters of PV array, PM DC motor and the load pump. 
ENHANCEMENT MAXIMUM POWER POINT TRACKING OF PV SYSTEMS USING DIFFERENT ALGORITHMS

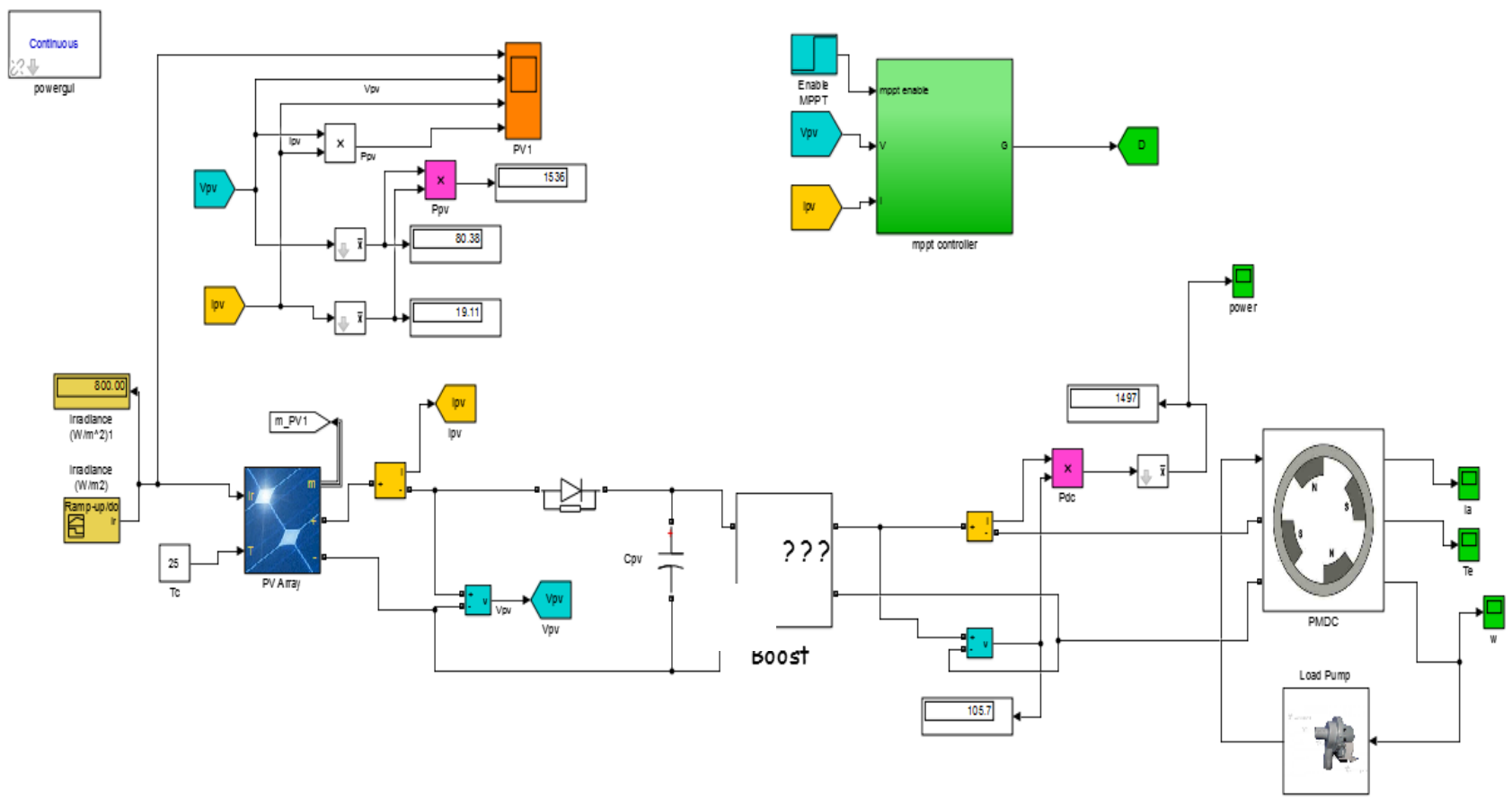

Fig.7 MATLAB Simulink model of MPPT for a PV module.
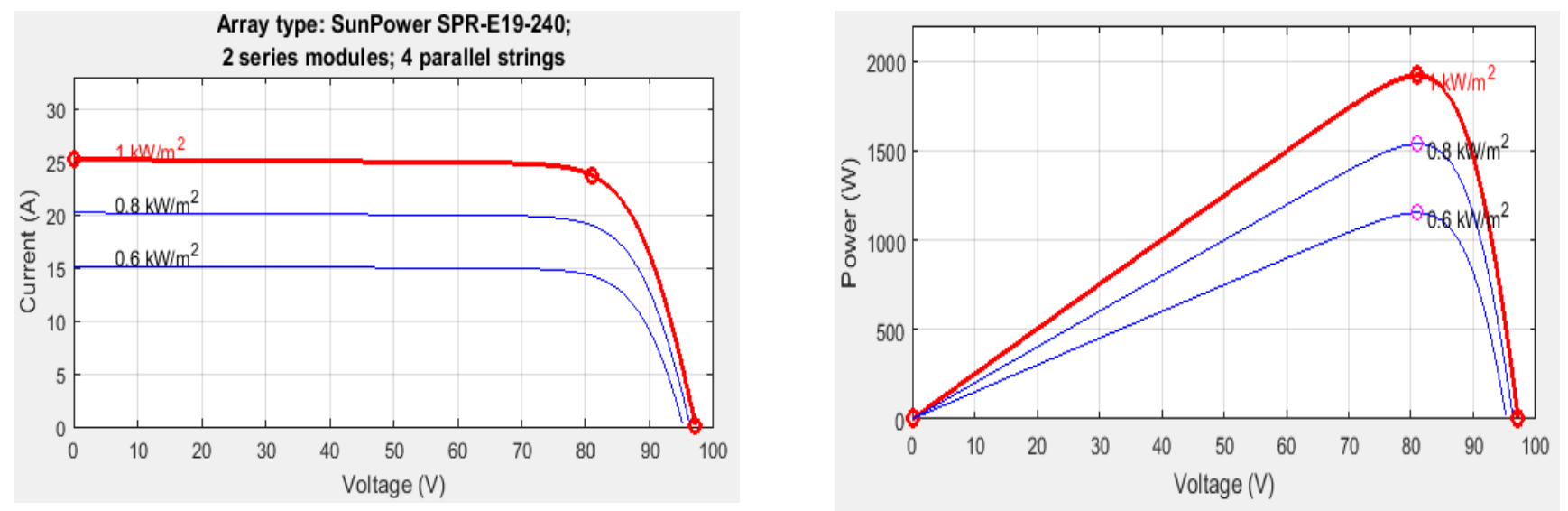

Fig.8 I-V and P-V characteristics of a typical PV array 
Table I. Parameters of PV array, PM DC motor and the load pump

\begin{tabular}{|c|c|}
\hline \multicolumn{2}{|c|}{ PV module data (Sun Power E19/240 solar panel) } \\
\hline Maximum power (Pmax) & $240 \mathrm{~W}$ \\
\hline $\begin{array}{l}\text { Maximum power point voltage } \\
\left(V_{m p p}\right)\end{array}$ & $40.5 \mathrm{~V}$ \\
\hline $\begin{array}{c}\text { Maximum power point } \\
\text { current }\left(I_{m p p}\right)\end{array}$ & $5.93 \mathrm{~A}$ \\
\hline Open circuit voltage $\left(\mathrm{V}_{\mathrm{oc}}\right)$ & $48.6 \mathrm{~V}$ \\
\hline Short circuit current $\left(\mathrm{I}_{\mathrm{sh}}\right)$ & $6.30 \mathrm{~A}$ \\
\hline Cells per module & 72 \\
\hline Parallel strings & 4 \\
\hline $\begin{array}{l}\text { Series-connected modules per } \\
\text { strings }\end{array}$ & 2 \\
\hline \multicolumn{2}{|c|}{ DC PM Motor data } \\
\hline Rated motor voltage $\left(\mathrm{V}_{\mathrm{a}}\right)$ & $120 \mathrm{~V}$ \\
\hline Rated motor current $\left(\mathrm{I}_{\mathrm{a}}\right)$ & $9.2 \mathrm{~A}$ \\
\hline Rated motor speed $(\omega)$ & $1500(\mathrm{rad} / \mathrm{sec})$ \\
\hline Armature resistance $\left(\mathrm{R}_{\mathrm{a}}\right)$ & $1.5 \Omega$ \\
\hline Armature inductance $\left(\mathrm{L}_{\mathrm{a}}\right)$ & $0.2 \mathrm{H}$ \\
\hline Voltage constant $\left(\mathrm{K}_{\mathrm{e}}\right)$ & $0.67609 \mathrm{~V} /(\mathrm{rad} / \mathrm{sec})$ \\
\hline Torque constant $\left(\mathrm{K}_{\mathrm{T}}\right)$ & $0.67609 \mathrm{Nm} / \mathrm{A}$ \\
\hline \multicolumn{2}{|c|}{ Load Pump data } \\
\hline Moment of inertia $(\mathrm{J})$ & $0.02365 \mathrm{Kg} \cdot \mathrm{m}^{2}$ \\
\hline Friction coefficient $(\mathrm{B})$ & $0.002387 \mathrm{Nm} /(\mathrm{read} / \mathrm{sec})$ \\
\hline Load torque constant $\left(\mathrm{k}_{\mathrm{L}}\right)$ & $0.00059 \mathrm{Nm} /(\mathrm{read} / \mathrm{sec})$ \\
\hline Load friction $\left(\mathrm{A}_{\mathrm{L}}\right)$ & $0.3 \mathrm{Nm}$ \\
\hline
\end{tabular}

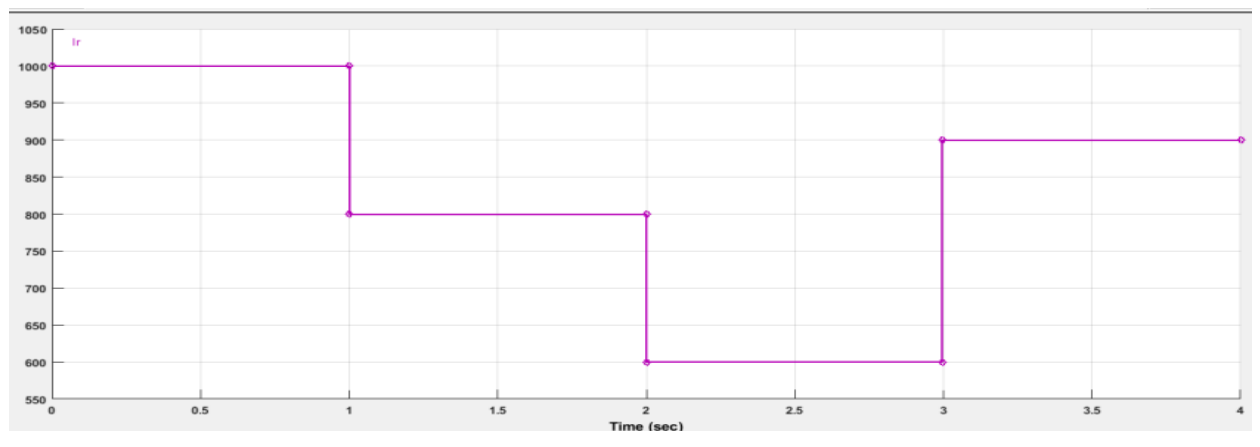

Fig. 9 Changing Irradiation level for comparison of P\&O and INC based controller. 


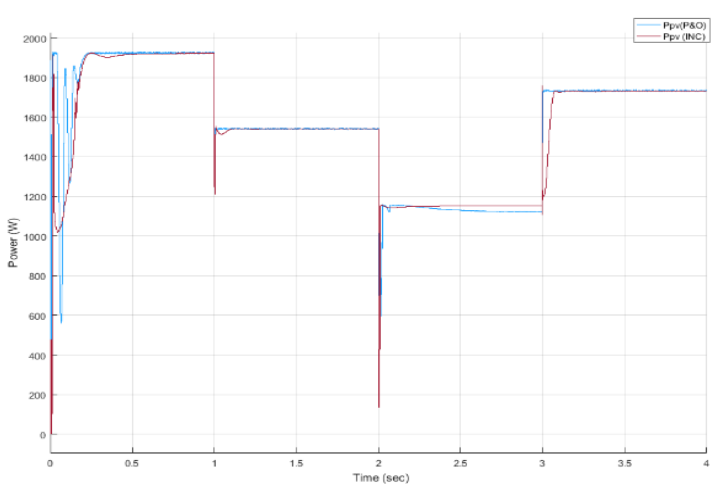

a

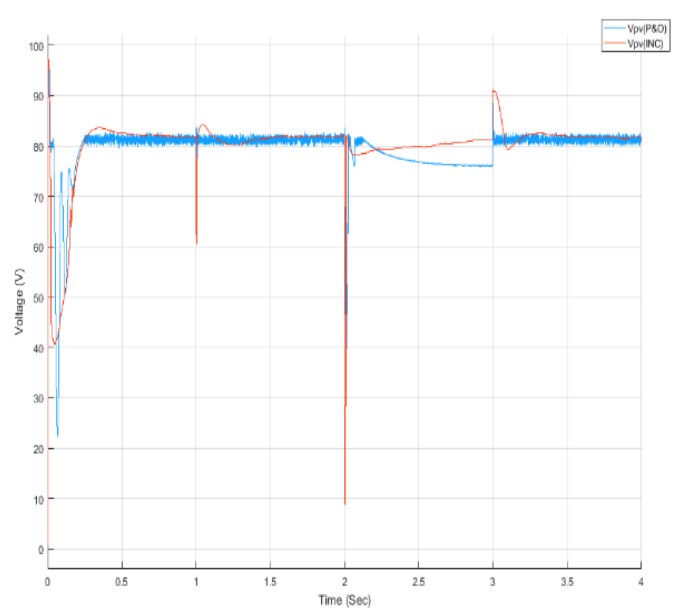

$\mathrm{b}$

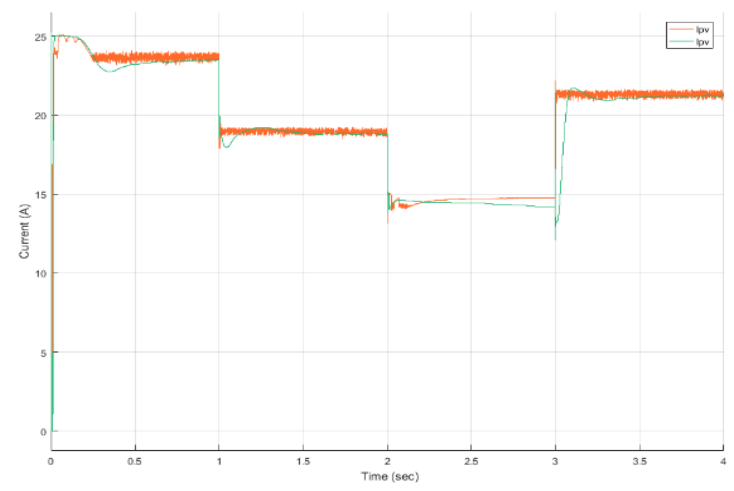

$\mathrm{c}$

Fig.10 output power, voltage and current under different irradiance with $P \& O$ algorithm and incremental conductance algorithm.

To analyse and compare the performance of the MPPT method, we carried out the simulation for temperature is constant $\left(25^{\circ} \mathrm{C}\right)$ and the irradiance change from $1000 \mathrm{~W} / \mathrm{m}^{2}$ to $800 \mathrm{~W} / \mathrm{m}^{2}, 600 \mathrm{w} / \mathrm{m}^{2}$ and then increases to $900 \mathrm{~W} / \mathrm{m}^{2}$ as shown in Fig.9 and Fig10. (a) (b),(c) show output power, voltage and current under different irradiance with $\mathrm{P} \& \mathrm{O}$ algorithm and incremental conductance algorithm.

In order to validate the effectiveness of two MPPT methods, a comparative study is done between $\mathrm{P} \& \mathrm{O}$ and incremental conductance. The static tracking efficiency of two MPPT methods under different irradiance are simulated. The static MPPT efficiency is given by:

$$
\eta_{\text {static }}=\frac{\text { Po }}{\text { Pmax }}
$$

Where $\mathrm{P}_{\mathrm{o}}$ represents the output power of the PV module under steady state, $\mathrm{P}_{\max }$ is the maximum power of the PV module under certain conditions[12]. From the results in Table II the static tracking efficiency of Perturb and Observe method is higher than Incremental Conductance method. 
ENHANCEMENT MAXIMUM POWER POINT TRACKING OF PV SYSTEMS USING DIFFERENT ALGORITHMS

Table II: Tracking efficiency of MPPT during irradiance change

\begin{tabular}{|c|c|c|c|c|c|}
\hline \multirow{4}{*}{ Theory } & $\mathrm{G}\left(\mathrm{W} / \mathrm{m}^{2)}\right.$ & 1000 & 800 & 600 & 900 \\
\cline { 2 - 6 } & $\mathrm{P}(\mathrm{W})$ & 1921 & 1540 & 1156 & 1731 \\
\cline { 2 - 6 } & $\mathrm{V}(\mathrm{V})$ & 82.1 & 81.2 & 81 & 81.7 \\
\cline { 2 - 6 } & $\mathrm{I}(\mathrm{A})$ & 23.4 & 18.96 & 14.27 & 21.18 \\
\hline \multirow{4}{*}{$\mathrm{P} \& \mathrm{O}$} & $\mathrm{P}(\mathrm{W})$ & 1920.5 & 1539.75 & 1154 & 1730.5 \\
\cline { 2 - 6 } & $\mathrm{V}(\mathrm{V})$ & 81.63 & 80.98 & 80.55 & 81.9 \\
\cline { 2 - 6 } & $\mathrm{I}(\mathrm{A})$ & 23.5 & 19.01 & 14.32 & 21.12 \\
\cline { 2 - 6 } & $\prod$ & $99.97 \%$ & $99.98 \%$ & $99.82 \%$ & $99.97 \%$ \\
\hline \multirow{3}{*}{ INC } & $\mathrm{P}(\mathrm{W})$ & 1919.5 & 1538.75 & 1152 & 1730.25 \\
\cline { 2 - 6 } & $\mathrm{V}(\mathrm{V})$ & 82.16 & 81.22 & 80.25 & 82.15 \\
\cline { 2 - 6 } & $\mathrm{I}(\mathrm{A})$ & 23.36 & 18.96 & 14.35 & 21.06 \\
\cline { 2 - 6 } & $\prod$ & $99.92 \%$ & $99.91 \%$ & $99.65 \%$ & $99.95 \%$ \\
\hline
\end{tabular}

\section{CONCLUSIONS}

This paper presents comparison between the performance of $\mathrm{P} \& \mathrm{O}$ and INC algorithms for PV pumping system. A MATLAB/ Simulink model is built. The two methods are tested under the same atmospheric conditions, when the irradiance is varying. The simulation results, it is clear that the $\mathrm{P} \& \mathrm{O}$ algorithm has a fast response time and it is not complex and easy to implement. However, $\mathrm{P} \& \mathrm{O}$ has oscillator behaviour around the MPP. The INC algorithm has a relatively slow response time compared to $\mathrm{P} \& \mathrm{O}$ method, and the implementation of the algorithm is considered to be complex. The performance comparison of two proposed MPPT is carried out at the same irradiation levels. The best results show that PV water pumping shows higher overall efficiency with two proposed MPPT techniques. However, the highest system efficiency obtained with the $\mathrm{P} \& \mathrm{O}$ technique than INC algorithm.

\section{REFERENCES}

[1] R. Illanes, A. De Francisco, J. Torres, M. De Blas, and J. Appelbaum, "Comparative study by simulation of photovoltaic pumping systems with stationary and polar tracking arrays," Progress in Photovoltaics: Research and Applications, vol. 11, pp. 453-465, 2003.

[2] M. Kolhe, S. Kolhe, and J. Joshi, "Determination of magnetic field constant of DC permanent magnet motor powered by photovoltaic for maximum mechanical energy output," Renewable Energy, vol. 21, pp. 563-571, 2000.

[3] A. D. Martin and J. R. Vazquez, "MPPT algorithms comparison in PV systems: P\&O, PI, neuro-fuzzy and backstepping controls," in Industrial Technology (ICIT), 2015 IEEE International Conference on, 2015, pp. 2841-2847.

[4] M. Rashid, "Power Electronics-Circuits, Devices, and Applications 3rd Edition Pearson Education," ed: Academic Pr, 2004.

[5] R. Krishnan, Switched reluctance motor drives: modeling, simulation, analysis, design, and applications: CRC press, 2001.

[6] W. R. Anis and H. M. Metwally, "Dynamic performance of a directly coupled PV pumping system," Solar Energy, vol. 53, pp. 369-377, 1994.

[7] A. Ghoneim, "Design optimization of photovoltaic powered water pumping systems," Energy conversion and management, vol. 47, pp. 1449-1463, 2006.

[8] J. Appelbaum, "Starting and steady-state characteristics of DC motors powered by solar cell generators," IEEE Transactions on Energy Conversion, pp. 17-25, 1986.

[9] A. Oi, "Design and simulation of photovoltaic water pumping system," California Polytechnic State University, 2005.

[10] G. Walker, "Evaluating MPPT converter topologies using a MATLAB PV model," Journal of Electrical \& Electronics Engineering, vol. 21, pp. 49-56, 2001.

[11] E. V. Solodovnik, S. Liu, and R. A. Dougal, "Power controller design for maximum power tracking in solar installations," IEEE Transactions on Power Electronics, vol. 19, pp. 1295-1304, 2004.

[12] T. Esram and P. L. Chapman, "Comparison of photovoltaic array maximum power point tracking techniques," IEEE Transactions on energy conversion, vol. 22, pp. 439-449, 2007. 